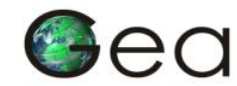

JURNAL PENDIDIKAN GEOGRAFI

\title{
PENGARUH APLIKASI MODEL ASSURE TERHADAP MOTIVASI DAN HASIL BELAJAR PESERTA DIDIK DALAM PEMBELAJARAN GEOGRAFI
}

\author{
Rosmalia Eva \\ Program Studi Pendidikan Geografi, SPs, UPI, \\ email: eva.rosmalia@ymail.com
}

\begin{abstract}
ABSTRAK
Motivasi belajar merupakan faktor yang mempengaruhi keberhasilan peserta didik dalam menempuh pembelajaran. Akan tetapi, Motivasi belajar peserta didik pada mata pelajaran geografi di SMA Negeri 1 Cikalongwetan masih rendah. Padahal, sarana dan prasarana pembelajaran yang berada di lingkungan sekolah cukup memadai. Karena itu, penelitian ini adalah untuk mengetahui pengaruh aflikasi model ASSURE untuk meningkatkan motivasi dan hasil belajar peserta didik di SMAN 1 Cikalongwetan. Metode penelitian menggunakan penelitian eksperimen (Quasi Experiment) dengan menggunakan Design Non-Equivalent, Pretest-Posttest Control Group Design.. Hasil penelitian menunjukkan bahwa pembelajaran dengan menggunakan desain model ASSURE dalam pembelajaran Geografi berpengaruh terhadap hasil belajar dan motivasi belajar peserta didik. Hal ini dapat diketahui dari hasil rata-rata pretes dan postes hasil belajar dan motivasi belajar peserta didik dalam pembelajaran Geografi.
\end{abstract}

Kata kunci: model assure, motivasi belajar, hasil belajar.

\section{PENDAHULUAN}

Manusia pada hakikatnya adalah mahluk sosial yang mendayagunakan potensi fisik dan psikis secara maksimal untuk memenuhi kebutuhan hidupnya. Sudrajat (2009) mengemukakan bahwa "manusia adalah mahluk Tuhan yang kompleks dan unik serta diciptakan dalam integrasi dua substansi yang tidak berdiri sendiri yaitu tubuh (fisik dan jasmani) sebagai unsur materi dan jiwa yang brsifat non materi". Karena kondisi manusia tersebut maka kebutuhan manusia terdiri atas dua macam yaitu kebutuhan material dan kebutuhan spiritual. Kebutuhan inilah yang menjadi arah dalam melangsungkan kehidupan melalui belajar.

Melalui belajar, manusia dapat memenuhi kebutuhan dan dapat berubah menjadi lebih baik. Perubahan-perubahan yang terjadi dari hasil belajar harus bersandar pada kesadaran, niat dan motivasi. Proses belajar berlangsung terus-menerus sehingga menimbulkan perubahan positif dalam hal perubahan moralitas dan keterampilan. Melalui belajar, potensi manusia dapat dikembangkan secara optimal.

Salah satu mata pelajaran di Sekolah Menengah Atas (SMA) adalah geografi. Dalam kurikulum geografi SMA dijelaskan bahwa tujuan pendidikan Geografi adalah untuk membangun kemampuan peserta didik dalam bersikap, bertindak cerdas, arif dan bertanggung jawab dalam menghadapi masalah sosial, ekonomi dan ekologis.

Pola pembelajaran di sekolah menuntut keaktifan siswa dalam belajar dan juga menuntut motivasi belajar yang tumbuh dari dalam diri siswa. Berdasarkan pemaparan hal tersebut diperlukan terobosan atau inovasi dalam kegiatan mengajar yang memudahkan peserta didik memahami materi yang diberikan oleh guru serta memu-dahkan penyampaian materi yang diajarkan. Untuk mengatasi permasalahan tersebut dibutuhkan desain pembelajaran yang lebih mudah diterima oleh peserta didik, memudahkan guru dalam menjelas- 
kan materi dan tidak monoton atau juga membosankan. Desain pembelajaran yang dibutuhkan yaitu desain pembelajaran model ASSURE (Analyze characteristic, State objectives, Select method, media and materials, Utilize media and materials, Require learner and Evaluate) berorientasi kegiatan belajar mengajar yang mampu memotivasi dan meningkatkan hasil belajar peserta didik.

Motivasi belajar merupakan faktor yang mempengaruhi keberhasilan peserta didik dalam menempuh pembelajaran. Motivasi belajar merupakan kondisi yang dapat mendorong peserta didik untuk melakukan suatu tindakan untuk mencapai tujuan pembelajaran. Motivasi dapat dikategorikan ke dalam motivasi intrinsik dan motivasi ekstrinsik.

Menurut Pribadi (2011:88) model ASSURE adalah model yang dalam pembelajarannya menddunakan media dan teknologi, implementasi teknologi dan media yang dapat digunakan oleh guru yaitu media cetak/teks, media pameran/ display, media audio, gambar bergerak/ motion pictures, multimedia dan media berbasis web atau internet.

Model ASSURE dikembangkan oleh Sharon Smaldino, Robert Heinich, James Russel dan Michael Molenda (2005) dalam buku "Intructional Technology and Media for Learning". Untuk menciptakan sebuah aktivitas pembelajaran yang efektif, diperlukan adanya sebuah proses perencanaan atau desain yang baik. Demikian pula dengan aktivitas belajar menggunakan media dan teknologi. Sama seperti model desain sistem pembelajaran yang lain, model ini dikembangkan untuk menciptakan aktivitas pembelajaran efektif dan efisien, khususnya pada kegiatan pembelajaran yang menggunakan teknologi media,

Langkah-langkah penting yang perlu dilakukan dalam model desain sistem pembelajaran ASSURE, meliputi beberapa aktivitas, yaitu: 1) Melakukan analisis karakteristik peserta didik/analyze learners, 2) Menetapkan tujuan pembelajaran/state objectives, 3) Memilih media, metode pembelajaran dan bahan ajar/select methods, media, and materials, 4) Melibatkan peserta didik dalam kegiatan pembelajaran/require learners participation, dan 5) Mengevaluasi dan merevisi program pembelajaran/ evaluate and revise

Ada enam indikator motivasi belajar peserta didik yang dikembangkan pada penelitian ini yaitu: (1) adanya hasrat dan keinginan berhasil, (2) adanya dorongan dan kebutuhan dalam belajar, (3) adanya penghargaan dalam belajar, (4) adanya harapan dan cita-cita masa depan, (5) adanya kegiatan yang menarik dalam belajar dan (6) adanya lingkungan belajar yang kondusif, sehingga memungkinkan peserta didik dapat belajar dengan baik (Hamzah, 2010:23).

Berdasarkan hasil observasi awal pada bulan September di SMA Negeri 1 Cikalongwetan, kelengkapan sarana dan prasarana pembelajaran yang berada di lingkungan sekolah cukup memadai, termasuk keberadaan laboratorium geografi yang seharusnya hasil belajar dan motivasi belajar peserta didik lebih baik.

Berdasarkan hasil wawancara dengan guru mata pelajaran Geografi bahwa di kelas belum pernah menggunakan desain pembelajaran model ASSURE. Saat ini desain pembelajaran yang digunakan oleh guru dalam proses belajar adalah desain pembelajaran konvensional yang akrab disebut dengan rencana pelaksanaan pembelajaran.

Rumusan masalah penelitiannya adalah 1) Bagaimana perbedaan motivasi belajar pada pengukuran akhir (postes) pada kelas eksperimen dan kelas kontrol? 2) Bagaimana kelemahan dan kelebihan model ASSURE dalam pembelajaran geografi materi lingkungan hidup?

\section{METODE PENELITIAN}

Metode penelitian yang digunakan dalam penelitian ini adalah penelitian eksperimen (quasi experiment) dengan menggunakan design non-equivalent, pretestposttest control group design.. Di dalam 
penelitian eksperimen terdapat kelompok eksperimen dan kelompok kontrol. Kedua kelompok tersebut sedapat mungkin homogen atau mendekati sama karakteristiknya. Sebagai kelas eksperimen yaitu kelas XI IPS 2 dan untuk kelas kontrol yaitu kelas XI IPS 4 karena kelas dengan rata-rata hasil UAS homogen.

\section{HASIL DAN PEMBAHASAN}

Pengaruh Model ASSURE terhadap Motivasi dan Hasil Belajar Peserta didik

Hasil penelitian menunjukkan bahwa pembelajaran geografi dengan menggunakan desain model ASSURE berpengaruh terhadap hasil belajar dan motivasi belajar peserta didik. Hal ini dapat diketahui dari hasil rata-rata pretes dan postes peserta didik dalam pembelajaran geografi pada materi Kerusakan Lingkungan Hidup dan
Upaya Pelestarian Lingkungan. Hal tersebut disebabkan desain pembelajaran yang dirancang sebelum pembelajaran oleh guru sesuai pembelajaran yang diharapkan oleh siswa. Terdapat perbedaan hasil postes hasil belajar dan motivasi belajar di kedua kelas tersebut dikarenakan pada kelas eksperimen menggunakan perlakuan dengan merancang model ASSURE dan pada kelas kontrol tidak. Setelah dilakukan implementasi pembelajaran dengan menggunakan desain model ASSURE di kelas eksperimen, dengan hasil postesnya pada hasil belajar 73,55 dan pada motiasi belajar peserta didik 87,97 . Untuk menguatkan hasil analisis mengenai peningkatan skor maka dilakukan uji normalitas dan homogenitas yang hasil pengujiannya disajikan pada tabel 1.

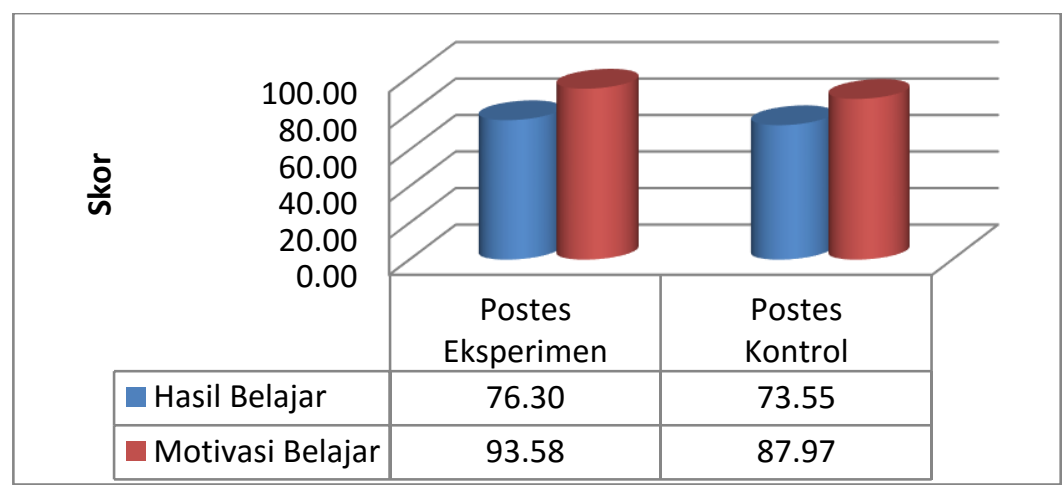

Gambar 1. Rata-rata Postes Kelas Eskperimen dan Kelas Kontrol

Tabel 1 Uji Normalitas dan Homogenitas Kelas Eksperimen-Kontrol

\begin{tabular}{|c|c|c|c|c|c|c|}
\hline $\begin{array}{l}\text { Sumber } \\
\text { Data }\end{array}$ & $\begin{array}{c}\text { Kelas Eksperimen } \\
\left(\mathrm{Sig}^{*}\right)\end{array}$ & Ket. & $\begin{array}{c}\text { Kelas Kontrol } \\
\left(\mathrm{Sig}^{*}\right)\end{array}$ & Ket. & Homogenitas (Sig**) & Ket. \\
\hline & Normalitas & & Normalitas & & & \\
\hline $\begin{array}{l}\text { Hasil } \\
\text { Belajar }\end{array}$ & 0,000 & $\begin{array}{l}\text { Nor } \\
\text { mal }\end{array}$ & 0,000 & $\begin{array}{c}\text { Tidak } \\
\text { Normal }\end{array}$ & 0,184 & $\begin{array}{l}\text { Hom } \\
\text { ogen }\end{array}$ \\
\hline $\begin{array}{c}\text { Motivasi } \\
\text { Belajar }\end{array}$ & 0,200 & $\begin{array}{l}\text { Nor } \\
\text { mal }\end{array}$ & 0,021 & $\begin{array}{c}\text { Tidak } \\
\text { Normal }\end{array}$ & 0,930 & $\begin{array}{l}\text { Hom } \\
\text { ogen }\end{array}$ \\
\hline
\end{tabular}

Berdasarkan tabel diperoleh hasil uji normalitas pada kelas eksperimen dan kelas kontrol tidak berdistribusi normal, akan tetapi bersifat homogen. Karena data tidak berdistribusi normal maka statistika yang digunakan yaitu statistika non parametrik sampel bebas Wilcoxon dengan taraf signifikansi $a=0,05$.
Tabel 2 Uji-T Hasil Belajar

Kelas Eksperimen-Kontrol

\begin{tabular}{lr}
\hline & $\begin{array}{r}\text { Postes Kon - Postes } \\
\text { Eks }\end{array}$ \\
\hline$Z$ & $-1.652^{\mathrm{b}}$ \\
Asymp. Sig. (2-tailed) & .099 \\
\hline a. Wilcoxon Signed Ranks Test \\
b. Based on positive ranks.
\end{tabular}


Dari tabel 2, diperoleh nilai $Z=-1,652$ dan taraf signifikansi (Sig.) 0,099 > 0,05 dengan demikian hipotesis menyatakan bahwa Ho diterima dan Ha ditolak, artinya tidak terdapat perbedaan yang signifikan antara skor postes kelas eksperimen dan skor postes pada kelas kontrol. Hal ini diperkuat dengan peningkatan motivasi belajar pada kesua kelas tersebut.

Tabel 3 Uji-T Motivasi Belajar Kelas Eksperimen-Kontrol

\begin{tabular}{lr}
\hline & \multicolumn{1}{c}{ Postest Kontrol - } \\
& Postest Eksperimen \\
\hline$Z$ & $-2.634^{\mathrm{b}}$ \\
Asymp. Sig. (2-tailed) & .008 \\
\hline a. Wilcoxon Signed Ranks Test \\
b. Based on positive ranks.
\end{tabular}

Uji-t digunakan untuk sampel bebas Wilcoxon karena salah satu data tidak berdistribusi normal dengan hasil berikut hasil pengujiannya. Berdasarkan uji-t tersebut diperoleh nilai $\mathrm{z}=-2.634$ dan Sig. 0,008 $<0,05$ dengan demikian dapat disimpulkan bahwa Ho ditolak dan H1 diterima, artinya adanya perbedaan motivasi belajar pada kelas eksperimen dan kelas kontrol pada pengukuran akhir (postes).

Terdapat empat indikator tanggapan peserta didik yang secara keseluruhan peserta didik memberikan tanggapan yang positif terhadap pembelajaran. Berikut analisis dari empat indikator tanggapan positif peserta didik tersebut: 1) Indikator angket yang menunjukkan perasaan senang terhadap desain pembelajaran Geografi model ASSURE dengan pemilihan Model Pembelajaran Numbered Head Together (NHT) dari 7 soal angket yang disebarkan diperoleh rata-rata 88,31 (88\%) dengan kategori sangat baik. Dengan kata lain peserta didik antusias dan senang dalam belajar Geografi dengan model ASSURE; 2) Indikator angket siswa yang menunjukkan ketertarikan terhadap tampilan gambar dan video dalam pembelajaran dari 8 soal angket diperoleh rata-rata 75,76 (76\%) dengan kategori sangat baik. Berdasarkan rekapitulasi tersebut peserta didik merasa sangat tertarik dengan tampilan gambar dan video dalam materi Kerusakan Lingkungan Hidup dan Upaya Pelestariannya; 3) Indikator angket yang menunjukkan kesungguhan dalam belajar materi Kerusakan Lingkungan Hidup dan Upaya Pelestarian Lingkungan Hidup dari 8 soal angket diperoleh rata-rata 84,09 (84\%) dengan kategori sangat baik; 4) Indikator angket yang menunjukkan keyakinan siswa untuk memahami isi materi Kerusakan Lingkungan Hidup dan Upaya Pelestarian Lingkungan Hidup dari 7 soal angket diperoleh rata-rata 85,28 (85\%) dengan kategori sangat baik.

Tanggapan positif yang dikemukakan oleh peserta didik menunjukkan bahwa fungsi dari media sesuai dengan gaya belajar yang siswa mampu memberikan kemudahan kepada siswa untuk mempelajari suatu materi baik secara mandiri ataupun dalam kelompok menurut kecepatan belajar masing-masing.

Edgar Dale dalam Dale's Cone of Experience yang dikutip oleh Sudjana dan Riva'i (1989:26) menggambarkan pentingnya visualisasi dan verbalistis dalam pengalaman belajar yang disebut kerucut pengalaman Edgar Dale (Cone of Experience) bahwa perlakuan dalam pembelajaran akan mempengaruhi terhadap motivasi belajar belajar peserta didik, semakin abstrak perlakuan dalam pembelajaran misalnya dengan ceramah yang menggunakan simbol, belajar dengan membaca maka pengalaman belajar yang diperoleh tidak terlalu besar. Sebaliknya pembelajaran dengan menggunakan media yang disertai dengan kemampuan atau gaya belajar siswa akan mengarahkan pada pengalaman belajar yang diperoleh secara maksimal. Pengalaman langsung yang siswa peroleh seperti membaca, mendengarkan, melihat gambar, menonton film, melihat langsung suatu kejadian, mempresentasikan dan melakukan diskusi. Hal ini tentunya akan meningkatkan hasil belajar siswa juga berimbas kepada motivasi belajar.

Ada enam indikator motivasi belajar peserta didik yang dikembangkan pada 
penelitian ini yaitu: (1) adanya hasrat dan keinginan berhasil, (2) adanya dorongan dan kebutuhan dalam belajar, (3) adanya penghargaan dalam belajar, (4) adanya harapan dan cita-cita masa depan, (5) adanya kegiatan yang menarik dalam belajar dan (6) adanya lingkungan belajar yang kondusif, sehingga memungkinkan peserta didik dapat belajar dengan baik (Hamzah, 2010:23). Perbandingan N-Gain motivasi belajar siswa setiap indikator ditunjukkan pada gambar 2 .

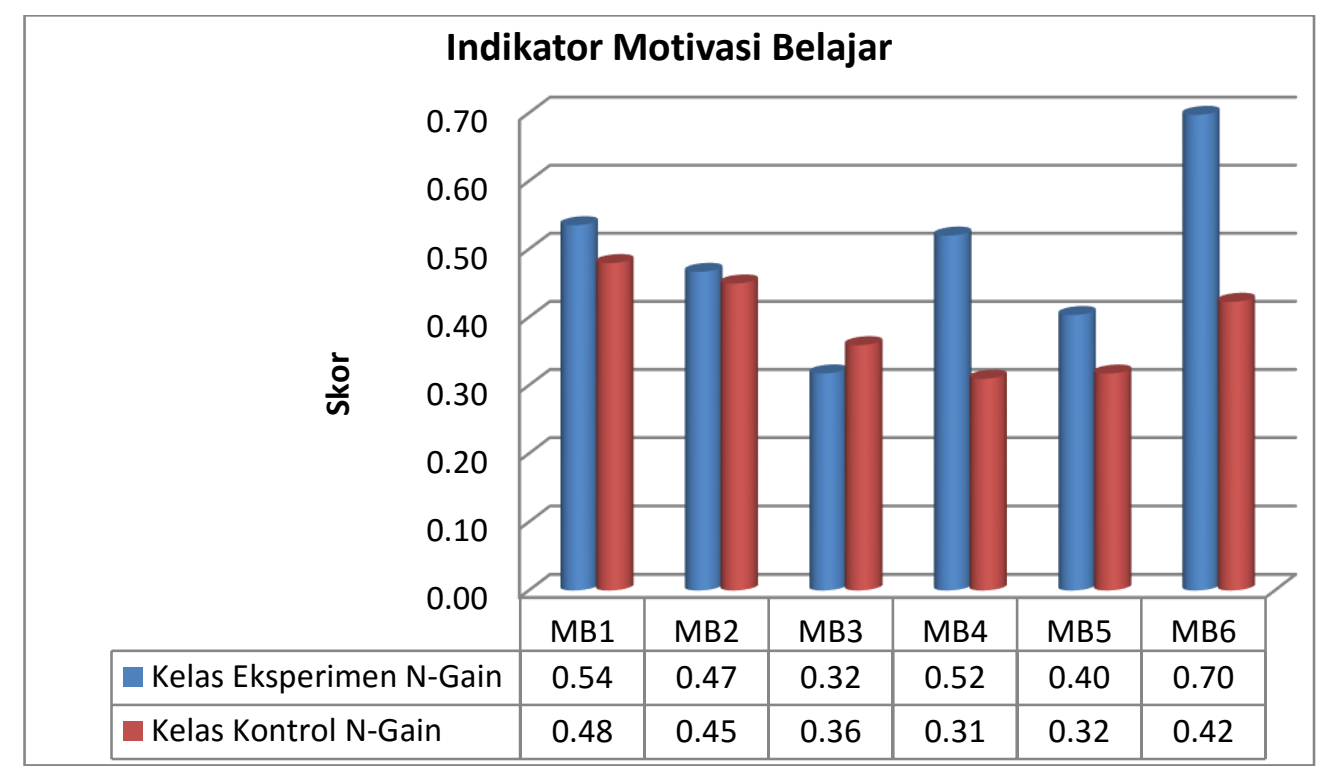

Gambar 2 Perbandingan N-Gain Motivasi Belajar Siswa untuk Setiap Indikator antara Kelas Eksperimen dan Kelas Kontrol

Berdasarkan gambar terlihat bahwa perolehan N-Gain pada kelas eksperimen tertinggi terjadi pada indikator ke-enam yaitu adanya lingkungan belajar yang kondusif, sehingga memungkinkan peserta didik dapat belajar dengan baik sebesar 0,70 dengan kategori tinggi dan nilai terendah N-Gain terjadi pada indikator ketiga yaitu adanya penghargaan dalam belajar sebesar 0,32 dengan kategori sedang. Pada kelas kontrol N-Gain tertinggi terjadi pada indikator pertama yaitu adanya hasrat dan keinginan berhasil sebesar 0,48 dengan kategori sedang dan $\mathrm{N}$ Gain terendah terjadi pada indikator keempat yaitu adanya harapan dan cita-cita masa depan sebesar 0,31 dengan kateogri sedang. Berdasarkan data tersebut dapat diketahui bahwa peningkatan N-Gain motivasi belajar siswa pada kelas eksperimen pada setiap indikator lebih tinggi dibandingkan dengan kelas kontrol.

Hasil penelitian ini menguatkan pandangan Fathurrohman (2007: 20-21) mengungkapkan ada beberapa strategi untuk menumbuhkan motivasi belajar peserta didik yakni: 1) menjelaskan tujuan belajar ke peserta didik, 2) hadiah, 3) saingan/kompetisi, 4) pujian, 5) hukuman, 6) membangkitkan dorongan kepada peserta didk untuk belajar, 7) membentuk kebiasaan belajar yang baik, 8) membantu kesulitan belajar peserta didik, baik secara individual maupun komunal (kelompok), 9) menggunakan metode bervariasi dan 10) menggunakan media yang baik serta harus sesuai dengan tujuan pembelajaran.

Dengan demikian, semakin jelas bahwa tugas guru harus senantiasa mampu untuk mencoba menganalisis, memahami, menguji coba, bahkan mengelaborasikan ke 10 unsur pada strategi menumbuhkan motivasi dalam belajar dalam mengikuti pembelajarannya.

Kelemahan dan Kelebihan Model ASSURE terhadap Pembelajaran Geografi Materi Kerusakan Lingkungan Hidup

Berdasarkan hasil aplikasi model ASSURE pada pembelajaran Geografi 
materi Kerusakan Lingkungan Hidup dan Upaya Pelestarian Lingkungan Hidup dengan pemilihan model pembelajaran di kelas Numbered Head Together (NHT) memiliki keunggulan dan kelemahan. Keunggulannya adalah a) pembelajaran berpusat pada siswa; b) siswa lebih cepat memahami pembelajaran; c) meng-cover siswa yang memiliki gaya belajar yang audio atau kinestetik dengan pemilihan model pembelajaran Numbered Head Together (NHT) berbasis media dan teknologi ; d) siswa aktif dan termotivasi dalam mengerjakan soal yang diberikan; e) ketersediaan sarana dan prasarana di sekolah yang memadai dengan adanya Laboratorium Geografi. f) guru menjadi sangat terbantu karena dengan pemilihan media audio-visual lebih mudah didapat dengan kemudahan mengakses media tersebut lewat internet di lingkungan sekolah, apalagi ditunjang dengan keberadaan laboratorium Geografi di sekolah. Hal ini memberikan kesan yang positif dari guru karena dapat membantu guru menjelaskan materi Kerusakan Lingkungan Hidup dan Upaya Pelestariannya kepada peserta didik. g) guru tidak lagi mendominasi kegiatan pembelajaran terutama dalam hal menyampaikan materi karena siswa dapat mempelajari dengan cara berkelompok, h) peserta didik lebih mudah memahami materi yang disampaikan karena ditunjang dengan gaya belajar yang dimiliki, i) suasana pembelajaran menjadi lebih menyenangkan karena dengan mengetahui gaya belajar peserta didik menjadi lebih termotivasi dalam belajar, j) penggunaan desain model ASSURE pada pemilihan pembelajaran kooperatif NHT (Numbered Head Together) dapat mengarahkan peserta didik untuk mencapai tujuan kognitif, afektif dan psikomotor. Dalam hal ini, menurut Sumaatmadja (1980:101-102) bahwa, "dalam berdiskusi aspek kognitif dalam bentuk inkuiri, aspek afektif dalam bentuk minat dan menghargai pendapat orang lain dan aspek psikomotor dalam bentuk ketangkasan menanggapi persoalan serta menganalisanya secara serentak dapat dikembangkan". Metode pembelajaran kooperatif/diskusi pada pembelajaran geografi baik ditinjau dari pelasksanaannya maupun hasil yang dicapainya dapat memunculkan karakter rasa tanggung jawab, berani merumuskan jawabanjawaban atau keputusan-keputusan yang harus diambil, percaya diri dan kompetitif. k) desain model ASSURE dapat digunakan berulang-ulang apabila gaya belajar siswa pada kelas tersebut sama yaitu visual dengan didukung sarana dan prasarana penunjangnya. Selain itu desain model ASSURE hanya sesuai diimplementasikan di sekolah-sekolah dengan kelengkapan media berteknologi yang cukup lengkap misalnya laboratorium Geografi yang ditunjang dengan komputer.

Kelemahan dari pembelajaran menggunakan desain model ASSURE pada pembelajaran Geografi materi Kerusakan Lingkungan Hidup dan Upaya Pelestarian Lingkungan Hidup dengan pemilihan model pembelajaran di kelas Numbered Head Together (NHT) seperti beberapa siswa belum terbiasa presentasi dengan maksimal, terlihat ketika membacakan hasil diskusinya siswa suaranya cenderung pelan dan gugup.

\section{SIMPULAN}

Model pembelajaran di sekolah bervariasi, setiap model memiliki keunggulan dan kelemahan masing-masing, termasuk dalam hal ini model ASSURE yang dikembangkan di sekolah. Hasil penelitian menunjukkan bahwa pembelajaran dengan menggunakan desain model ASSURE dalam pembelajaran Geografi berpengaruh terhadap hasil belajar dan motivasi belajar peserta didik. Hal ini dapat diketahui dari hasil rata-rata pretes dan postes motivasi belajar peserta didik dalam pembelajaran geografi pada materi Kerusakan Lingkungan Hidup dan Upaya Pelestarian Lingkungan. Sesungguhnya model ASSURE ini tidak hanya memotivasi belajar 
peserta didik tetapi dapat pula Heinich, dkk., (2005). Intructional Media and meningkatkan hasil belajar peserta didik. Technologies for Learning Seventh Edition. Hal tersebut disebabkan karena desain New Jersey: Upper Saddle River.

pembelajaran yang dirancang sebelum Pribadi, Benny. A. (2011). Model Assure pembelajaran oleh guru sesuai dengan Untuk Mendesain Pembelajaran Sukses. pembelajaran yang diharapkan oleh siswa.

\section{DAFTAR PUSTAKA} Jakarta: Dian Rakyat.

Sudjana, N. dan Rivai. (1989). Teknologi Pengajaran. Jakarta: Grasindo.

Fathurrohman, Pupuh., dan Sutikno,M. Sudrajat, Iskandar Ridwan. (2009). Sumber Sobry (2007). Strategi Belajar Mengajar Daya Manusia. [online]. Tersedia: Melalui Penanaman Konsep Umum dan Konsep Islami. Reflika Aditama: Bandung. Hamzah, Uno. (2010). Desain Pembelajaran. Bandung: Publishing. http:// ridwaniskandar.files.wordpress.c om/2009/05/1-pengertian-sdm.pdf. [24 Desember 2013]. 